\title{
Characterization of Manganese Alloy Residues for the Recycling of FeSiMn and High-Carbon FeMn fines
}

\author{
Geraldo Lúcio de Faria*, Érica Linhares Reis ${ }^{\text {a }}$,Fernando Gabriel da Silva Araújo ${ }^{\text {a }}$ \\ Cláudio Batista Vieira ${ }^{\mathrm{a}}$,Fernando Leopoldo von Krüger ${ }^{\mathrm{b}}$, Nelson Jannotti Jr. ${ }^{\mathrm{c}}$ \\ a Programa de Pós-Graduação em Engenharia de Materiais/REDEMAT/UFOP \\ Praça Tiradentes 20, Centro, Ouro Preto - MG, Brazil \\ ${ }^{\mathrm{b}}$ Fundação Gorceix \\ Logradouro 390, Gleba B, Vila Itacolomi, Ouro Preto - MG, Brazil \\ ${ }^{c}$ Manganese and Alloys Department, Companhia VALE \\ Rancharia, s/n, zona rural, Ouro Preto - MG, Brazil
}

Received: December 6, 2007; Revised: November 12, 2008

\begin{abstract}
Crushing residues of FeSiMn and high-carbon (HC) FeMn alloys were characterized in order to evaluate their recycling possibility. Particle size determination was performed by screening, followed by chemical analysis of each particle size range using plasma spectrometry (ICP-AES). The slag content was identified and quantified by optical microscopy. All of the fines with grain sizes above $1.18 \mathrm{~mm}$ presented alloy contents in excess of $99 \mathrm{wt} .(\%)$ and were determined to need no further concentration prior to recycling. However the contents of Mn, $\mathrm{Fe}, \mathrm{Si}$ and $\mathrm{P}$ in the fraction below $1.18 \mathrm{~mm}$ did not meet the chemical specifications for commercial manganese alloys, except for phosphorous. Optical microscopy of the fraction below $1.18 \mathrm{~mm}$, showed that $87.95 \%$ of the FeSiMn corresponded to the alloy and that the slag content was $12.05 \%$. For the HC-FeMn sample, $95.07 \%$ corresponded to the alloy and only $4.93 \%$ to the slag. These results revealed potential for gravity concentration and recycling, reducing the residues in about $95 \%$ and improving the process productivity.
\end{abstract}

Keywords: materials characterization, manganese alloys, solid residues

\section{Introduction}

The use of ferromanganese alloys is a common and important practice in steelmaking. They are incorporated into the steel to improve its properties ${ }^{1,2,3}$. The alloys are more effective than pure metals, as they have lower melting point, density and production cost. Another important use of these alloys in steelmaking is in the final stage of steel refining, during oxygen removal ${ }^{3,4}$.

It is well known that both high carbon-FeMn (HC-FeMn) and FeSiMn alloys are produced by carbothermic reduction of manganese ores at high temperatures in electric arc furnaces (EAF). The HC-FeMn alloy can also be produced in blast furnace. However, this blast-furnace-produced alloy represents only a small part of the HC-FeMn produced worldwide ${ }^{2,3}$.

For HC-FeMn production, the ore mixture should contain high manganese content in relation to the iron content $(7: 1)$. Besides this, the mixture should contain sufficient silica to form a slag with manganese oxide and sufficient alumina to ensure that, from this slag, one can produce FeSiMn having a higher Si and lower $\mathrm{C}$ content ${ }^{5,6,7}$

The HC-FeMn alloy, at Rancharia Vale's unit, located in Ouro Preto (MG), has the following specifications: 74 to $78 \%$ manganese, $1.5 \%$ silicon, 0.15 a $0.30 \%$ phosphorous, a maximum of $7.5 \%$ carbon and a maximum of $0.03 \%$ sulfur. The FeSiMn alloy has the specifications: 65 to $70 \%$ manganese, 0.15 to $0.20 \%$ phosphorus, 1.8 to $2.5 \%$ carbon and less than $0.03 \%$ sulfur.

The final products are HC-FeMn and FeSiMn alloys. The byproducts are the low density slags, which float on top of the metal, and the small size residues, which result from crushing the alloy. For obtaining commercial alloys, two stages are extremely important.
The first is in the alloys discharge from the furnace, where the alloy and slag are separated, generally by the Skimmer process ${ }^{8}$, in which a lower level channel collects the alloy and a higher level channel collects the floating slag. The only mechanism responsible for separating the alloy from slag is density diferentiation. As slag volume varies from batch to batch, there is an upper portion of the alloy, close to the pure slag region, that is often contaminated by it. The alloy is in constant contact with the slag, and a fraction of the slag solidifies within the superimposing layers of alloy from subsequent batches deposited in a solidification pool ${ }^{9}$.

The second stage produces lump alloys by comminution of the ingots by jaw crushers according to the application requirements, usually between 6.3 and $50.0 \mathrm{~mm}$, in order to be directly feed to the LD and EAF in steel plants. Crushing process produces as residues the alloy fines, consisting of particles smaller than $6.3 \mathrm{~mm}$, which typically represent between 10 and $15 \mathrm{wt}$. (\%) of the production. As the contamination slag present in the alloy ingots is much more fragile than the alloy itself, it tends to break into finer particles and concentrate in the crushing residues. Therefore, in order to promote recycling or commercialization of the alloy fines, the slag must be removed from it.

Residual manganese alloy fines are classified as solid residues containing heavy metals (typically $\mathrm{Co}, \mathrm{As}, \mathrm{Pb}$ and $\mathrm{Zn}$ ) and await the determination of effective processes for their recycling. As there are no specific references of such material, this paper describes the characterization of the fines, in order to assist the determination of 
alternate routes for their processing which could improve the overall economy of the manganese alloy production.

\section{Materials and Methods}

The particle size distribution of both FeSiMn and HC-FeMn fines were carried out by dry screening with grids ranging from 9.53 to $0.037 \mathrm{~mm}$ (Tyler series).

Quantitative chemical analyses were carried out in both fractions, $>1.18 \mathrm{~mm}$ and $<1.18 \mathrm{~mm}$, to determine $\mathrm{Mn}, \mathrm{Fe}$, Si and P concentrations. The method used for this analysis was atomic emission spectrometry from a plasma source (ICP-AES).

Alloy and slag concentrations, as well as free slag fraction were determined by quantitative microscopy analysis in a polarizing metallographic microscope LEICA. Samples with different particle sizes were prepared in polished sections for embedding in a polyurethane resin. Alloy and slag concentrations were determined by their bulk fraction in polished section. The method is based on the difference in optical properties. The number of alloy and slag particles is counted, as well as the number of black spots (porosity). These numbers are transformed into volume fraction, based on slag and alloy density for bulk proportional relation. The free slag fraction is the bulk fraction of slag which is not aggregated to an alloy particle ${ }^{10}$.

\section{Results and Discussions}

In the first screening procedure, the manganese alloys fines showed $52.12 \%$ of HC-FeMn and $51.93 \%$ of FeSiMn above $1.18 \mathrm{~mm}$. Chemical analysis of the HC-FeMn and FeSiMn fines in this range are shown in Table 1. HC-FeMn and FeSiMn fines above $1.18 \mathrm{~mm}$ have, respectively, 99.9 and $99.8 \%$ of alloy content, thus practically no slag is present in this particle size range, and the material can be considered as pure alloy. This portion of the fines can be directly fed to the electric arc furnaces, immediately reducing the residues in more than $50 \%$, by its recycling.

The particle size distributions of the manganese alloys fines below $1.18 \mathrm{~mm}$ are presented in Figure 1. For FeSiMn below $1.18 \mathrm{~mm}$, it was observed that $55.97 \%$ of the particles were smaller than $0.594 \mathrm{~mm}$. The numbers obtained were $\mathrm{d}_{50}=0.5 \mathrm{~mm}$ and $\mathrm{d}_{80}=0.90 \mathrm{~mm}$, which

Table 1. Chemical analysis of manganese alloys fines above $1.18 \mathrm{~mm}$.

\begin{tabular}{ccccc}
\hline Sample & $\begin{array}{c}\text { Fe } \\
\text { wt. }(\%)\end{array}$ & $\begin{array}{c}\text { Mn } \\
\text { wt. }(\%)\end{array}$ & $\begin{array}{c}\text { Si } \\
\text { wt. }(\%)\end{array}$ & $\begin{array}{c}\text { P } \\
\text { wt. }(\%)\end{array}$ \\
\hline HC-FeMn & 16.5 & 70.4 & 3.2 & 0.27 \\
FeSiMn & 14.1 & 63.0 & 17.0 & 0.16 \\
\hline
\end{tabular}

means that 50 and $80 \%$ of the sample were smaller than 0.5 and $0.90 \mathrm{~mm}$ respectively. For the HC-FeMn below $1.18 \mathrm{~mm}$, it was observed that $56.90 \%$ of the particles were smaller than $0.420 \mathrm{~mm}$. The numbers obtained here were $\mathrm{d}_{50}=0.35 \mathrm{~mm}$ and $\mathrm{d}_{80}=0.70 \mathrm{~mm}$. Hence the HC-FeMn crushing residues are finer than the FeSiMn.

Chemical analyses of the HC-FeMn and FeSiMn fines below $1.18 \mathrm{~mm}$ are shown in Table 2, including the heavy metals $(\mathrm{Ni}, \mathrm{Co}$, $\mathrm{Cd}, \mathrm{As}, \mathrm{Pb}$ and $\mathrm{Zn}$ ). The phosphorus concentration met the chemical specifications for a commercial alloy in the HC-FeMn and FeSiMn fines. The concentration of the alloy elements in both the FeSiMn and $\mathrm{HC}-\mathrm{FeMn}$ fines were close to the commercial specifications, but not their size distribution.

Tables 3 and 4 present results of quantitative analysis by optical microscopy for different particle size ranges of FeSiMn and HC-FeMn. The free slag fraction represents the amount of the total content of slag that is not bonded to any alloy particle. Therefore, in the FeSiMn fines, the alloy particles are satisfactorily separated from the slag, with at least 0.67 free slag fraction.

The results show that the bigger the size range of the FeSiMn particles, the lower is the slag weight fraction. The largest slag concentration $(39.64 \%)$ was found for the particles smaller than $0.044 \mathrm{~mm}$. As an average, $87.95 \%$ of the FeSiMn fines $(<1.18 \mathrm{~mm})$ correspond to alloy and only $12.05 \%$ to slag.

Due to its brittleness, there is higher concentration of slag in the finer particle ranges, as during the crushing process, the slag produces

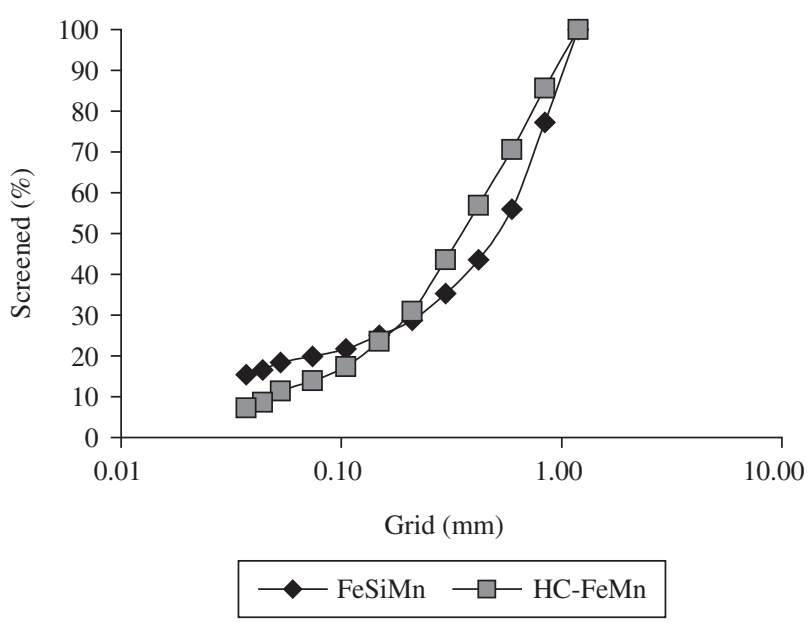

Figure 1. Particle size distribution of FeSiMn and HC-FeMn (for particles $<1.18 \mathrm{~mm}$ ).

Table 2. Chemical analysis of manganese alloys fines below $1.18 \mathrm{~mm}$.

\begin{tabular}{|c|c|c|c|c|c|c|c|c|c|c|}
\hline Sample & $\begin{array}{c}\mathrm{Fe} \\
\text { wt. }(\%)\end{array}$ & $\begin{array}{c}\mathrm{Mn} \\
\text { wt. }(\%)\end{array}$ & $\begin{array}{c}\mathrm{Si} \\
\text { wt. }(\%)\end{array}$ & $\begin{array}{c}\mathrm{P} \\
\text { wt. }(\%)\end{array}$ & $\begin{array}{c}\mathrm{Ni} \\
\text { wt. }(\%)\end{array}$ & $\begin{array}{c}\text { Co } \\
\left(\mathrm{mg} \cdot \mathrm{kg}^{-1}\right)\end{array}$ & $\begin{array}{c}\mathrm{Cd} \\
\left(\mathrm{mg} \cdot \mathrm{kg}^{-1}\right)\end{array}$ & $\begin{array}{c}\mathrm{As} \\
\left(\mathrm{mg} \cdot \mathrm{kg}^{-1}\right)\end{array}$ & $\begin{array}{c}\mathrm{Pb} \\
\left(\mathrm{mg} \cdot \mathrm{kg}^{-1}\right)\end{array}$ & $\begin{array}{c}\mathrm{Zn} \\
\left(\mathrm{mg} \cdot \mathrm{kg}^{-1}\right)\end{array}$ \\
\hline HC-FeMn & 16.2 & 64.3 & 19.3 & 0.29 & 0.096 & 722 & 16.2 & 109 & 123 & 77.7 \\
\hline FeSiMn & 14.3 & 57.6 & 27.8 & 0.30 & 0.089 & 634 & 15.3 & 134 & 96 & 80.4 \\
\hline
\end{tabular}

Table 3. Quantitative analysis of FeSiMn fines for slag and alloy content and the slag liberation fractions as a function of particle size.

\begin{tabular}{cccc}
\hline $\begin{array}{c}\text { Particle size } \\
(\mathrm{mm})\end{array}$ & Free slag fraction & \multicolumn{2}{c}{ Composition } \\
\cline { 3 - 4 }$>0.210$ & & FeSiMn alloy wt. (\%) & Slag wt. (\%) \\
$>0.105$ & 0.87 & 81.56 & 18.44 \\
$>0.075$ & 0.74 & 79.76 & 20.24 \\
$>0.044$ & 0.67 & 71.14 & 28.86 \\
$<0.044$ & 0.74 & 69.58 & 30.42 \\
\hline
\end{tabular}


Table 4. Quantitative analysis of HC-FeMn fines for slag and alloy content and the slag liberation fractions as a function of particle size.

\begin{tabular}{cccc}
\hline \multirow{2}{*}{$\begin{array}{c}\text { Particle size } \\
(\mathrm{mm})\end{array}$} & $\begin{array}{c}\text { Free slag } \\
\text { fraction }\end{array}$ & $\begin{array}{c}\text { HC-FeMn } \\
\text { Alloy wt. (\%) }\end{array}$ & $\begin{array}{c}\text { Slag } \\
\text { wt. (\%) }\end{array}$ \\
\hline$>0.210$ & 0.87 & 96.04 & 3.96 \\
$>0.105$ & 0.58 & 74.48 & 25.52 \\
$>0.075$ & 0.56 & 65.46 & 34.54 \\
$>0.044$ & 0.58 & 65.21 & 34.79 \\
$<0.044$ & 0.84 & 70.91 & 29.09 \\
\hline
\end{tabular}

more fines than the alloy. In the case of the HC-FeMn alloy particles, the liberation of the slag was not quite as high as for FeSiMn, presenting free slag fractions as low as 0.56 . However, in all particle size ranges, the alloy content was higher and the slag content lower than in the previous alloy. In the overall sample $(<1.18 \mathrm{~mm})$, it was observed that $95.07 \%$ was alloy and $4.93 \%$ was slag.

Quantitative analysis by optical microscopy of both the fines above $1.18 \mathrm{~mm}$, confirmed that for HC-FeMn $(>1.18 \mathrm{~mm})$ there was $99.9 \%$ of alloy content and for FeSiMn fines (>1.18 mm) $99.8 \%$ was alloy.

\subsection{Microstructual examination}

Figures 2 and 3 show typical microstructural examples, revealed under polarized light, of free and aggregated particles present in alloy fines, in which the predominant forms of interaction between alloy and slag can be seen. The alloy particles reflect light and are the shiny phase in the micrographs (a). The grey phase corresponds to the slag (b) and the dark features show either the presence of a fracture, or a pore, or a crystalline surface that is not perpendicular to the light rays (c). Figure 4 shows a free slag particle.

\section{Conclusions}

In the HC-FeMn fines, $52.12 \%$ of particles we re above $1.18 \mathrm{~mm}$. In the FeSiMn, $51.93 \%$ of particles were above $1.18 \mathrm{~mm}$. The HCFeMn and FeSiMn fines above $1.18 \mathrm{~mm}$ had, respectively, 99.9 and $99.8 \%$ of alloy content. Therefore, a simple screening operation at $1.18 \mathrm{~mm}$ could be an efficient HC-FeMn and FeSiMn fines concentration procedure.

The Mn, Fe and Si concentrations in both the HC-FeMn and FeSiMn fines below $1.18 \mathrm{~mm}$ did not meet chemical composition specifications for steelmaking. Nevertheless, the phosphorus concentration was acceptable in both fines samples.

In the FeSiMn and HC-FeMn fines samples below $1.18 \mathrm{~mm}$, about $56 \%$ of the particles were smaller than 0.594 and $0.420 \mathrm{~mm}$ respectively. The FeSiMn and HC-FeMn fines samples below $1.18 \mathrm{~mm}$ had 87.95 and $95.07 \%$ of alloy respectively. As a general rule, the smaller the particles size the bigger the slag concentration.

The free slag fractions, obtained for HC-FeMn and FeSiMn fines below $1.18 \mathrm{~mm}$ are suitable for gravity concentration (now under study).

\section{Acknowledgements}

The authors would like to thank VALE for supplying samples and the Fundação Gorceix from Ouro Preto - Brazil, for financial support.

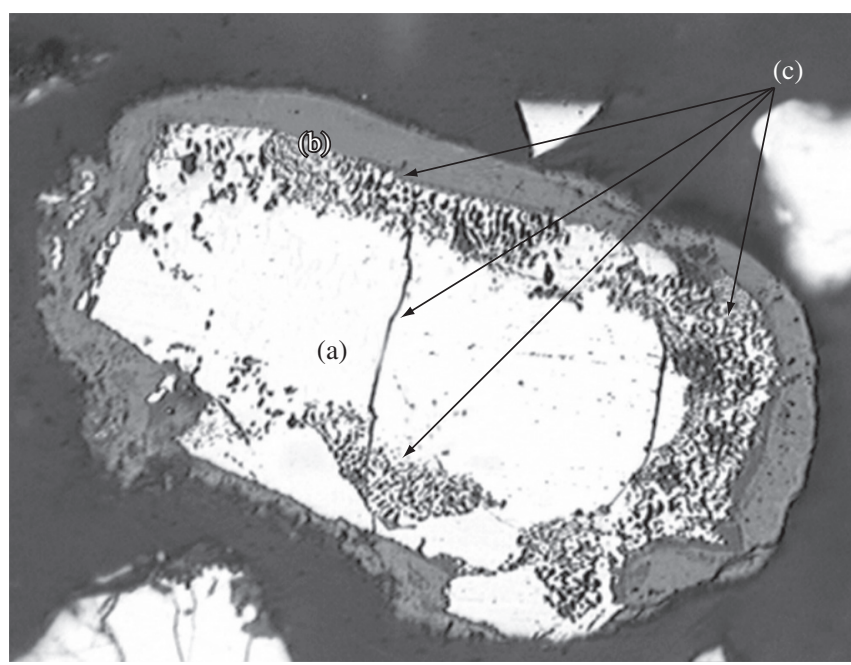

Figure 2. Optical micrograph of a HC-FeMn alloy particle aggregated to slag. 220x. a) alloy, b) slag, and c) pore/fracture.

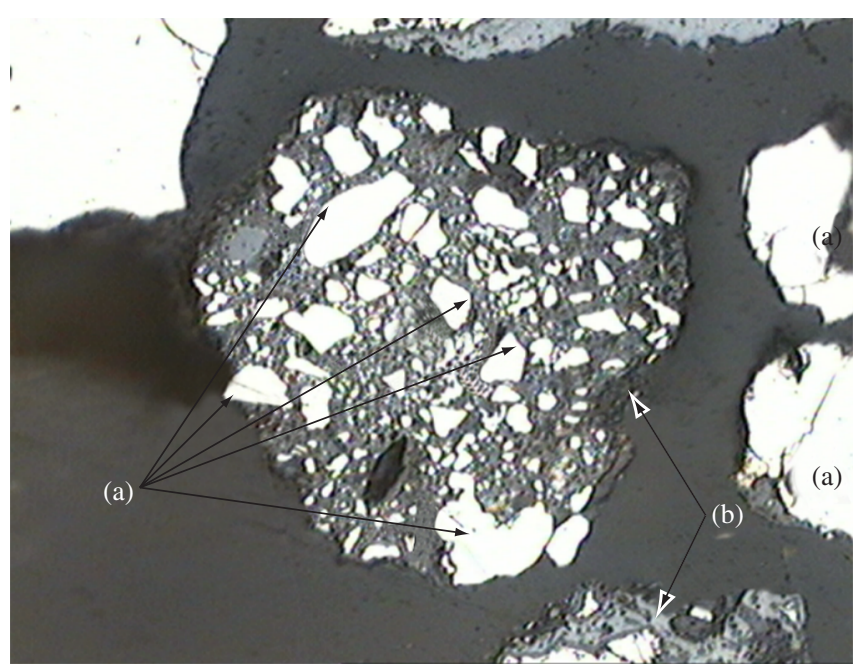

Figure 3. Optical Micrograph of FeSiMn alloy particles aggregated to slag. 220x. a) alloy, and b) slag.

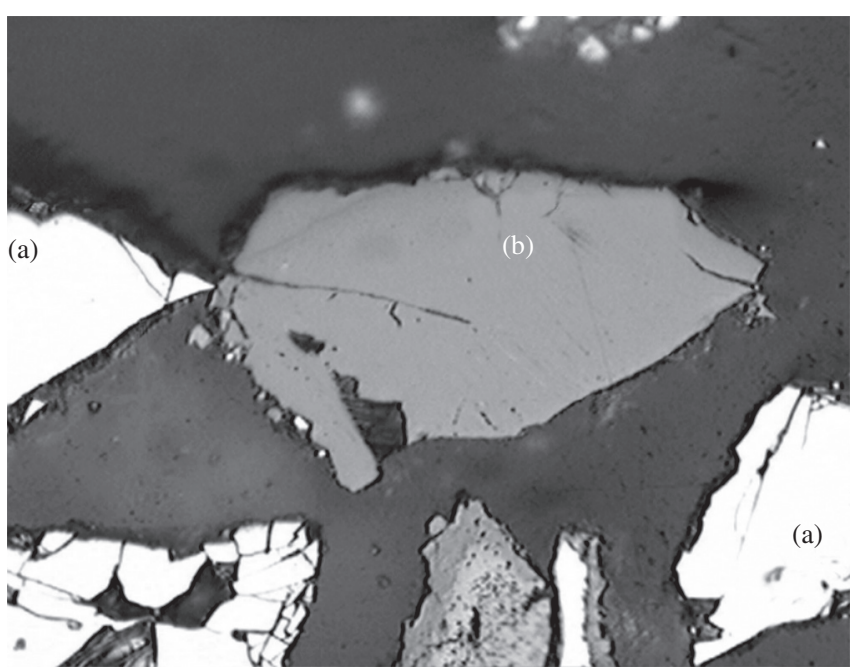

Figure 4. Optical Micrograph of a slag particle liberated from the HC-FeMn alloy. 220x. a) alloy, and b) slag. 


\section{References}

1. Ullmann F. Manganese and Manganese Alloys. In: Encyclopedia of Industrial Chemistry. 5 ${ }^{\mathrm{a}}$ edition. Weinhein, Germany: VCH; 1985. vol. $16 \mathrm{~A}, \mathrm{p} .77-133$.

2. Tangstad M, Olsen SE, Sverre, E. The Ferromanganese Process - Material and Energy Balance. In: 7 th International Ferroalloys Congress INFACON; 1995. Trondheim, Norway: NTH-TRYKK; 1995.

3. Tangstad M. Production of Ferromanganese Alloys in the Submerged Arc Furnace. Trondheim, Norway: Tapir Academic Press; 2007.

4. Riss A, Khodorovsky Y. Production of Ferroalloys. Moscow: Mir Publishers; 1967. p. 218-230.

5. Ding W, Kossyreva O, Olga A. Tangstad, M. Equilibrium in Production of High Carbon Ferromanganese. In: 7th International Ferroalloys CongressINFACON;1995. Trondheim, Norway: NTH-TRYKK; 1995. p. 591-600.
6. Ding W, Olsen SE. Manganese and Silicon Distribution between Slag and Metal in Silicomanganese Production. ISIJ International 2000; 40(9):850-856.

7. Ding W. Equilibrium Relations in the Production of Manganese Alloys. [Doctoral thesis]. Trondheim, Norway: Norwegian Institute of Technology; Feb. 1993.

8. Faria G. Caracterização Química e Estrutural de Matérias-Primas e Produtos de Ferro Ligas de Manganês. [Monografia]. Ouro Preto: Departamento de Física - UFOP; 2006.

9. Silveira RC, Lucio A, Mines CRC, Figueira RM, Sampaio RS, Castro LFA. Metalurgia dos ferro-ligas. Belo Horizonte: Escola de Engenharia, Universidade Federal de Minas Gerais; 1980.

10. Bérubé MA, Marchand JC. Estudes de libération des minerais à l'Université Laval (Québec). Montreal. CIM Bulletin 1983; 76(850): 54-64. 